Arq. Bras. Med. Vet. Zootec., v.71, n.4, p.1093-1099, 2019

\section{Cutaneous mycobiota of boid snakes kept in captivity}

[Microbiota cutânea de serpentes Boidae mantidas em cativeiro]
B.C. Freire1, 2 https://orcid.org/0000-0001-5495-174X V.C. Garcia 2,3* https://orcid.org/0000-0002-7605-8300 A.E. Quadrini 1, 2, https://orcid.org/0000-0003-0882-2757 H.D.L. Bentubo1, https://orcid.org/0000-0003-0091-2504

\author{
B.C. Freire ${ }^{1,2}$, V.C. Garcia $^{2,3^{*}}$, A.E. Quadrini ${ }^{1,2}$, H.D.L. Bentubo ${ }^{1}$ \\ ${ }^{1}$ Faculdade de Medicina Veterinária - Universidade Cruzeiro do Sul - São Paulo, SP \\ ${ }^{2}$ Instituto Butantan - São Paulo, SP \\ ${ }^{3}$ Aluno de pós-graduação - Faculdade de Medicina Veterinária e Zootecnia - Universidade de São Paulo, SP
}

\begin{abstract}
Boids are large, constrictor snakes that feed mostly on mammals, reptiles, and birds. These animals are commonly raised as pets, and their improper handling can favor the emergence of fungal infections, which can lead to dermatological diseases that are undiagnosed in nature. Here, we isolate and identify the filamentous fungi that compose the mycobiota of the scales of boid snakes kept in captivity at the Biological Museum of the Butantan Institute. Thirty individuals of four species were evaluated: four Eunectes murinus, twelve Boa constrictor constrictor, seven Corallus hortulanus, and seven Epicrates crassus. Microbiological samples were collected by rubbing small square carpets on the snake scales. We isolated five genera of fungi: Penicillium sp. (30\%), Aspergillus sp. (25\%), Mucor sp. (25\%), Acremonium sp. (10\%), and Scopulariopsis sp. (10\%). Approximately half of the snakes evaluated had filamentous fungi on the scales, but only $12 \%$ of the individuals were colonized by more than one fungal genus. We found no dermatophytes in the evaluated species. Our results provide an overview of the fungal mycobiota of the population of boids kept in the Biological Museum, allowing the identification of possible pathogens.
\end{abstract}

Keywords: microbiology, filamentous, fungi, reptiles

\title{
RESUMO
}

Boidae são serpentes grandes e constritoras, que comem normalmente mamíferos, répteis e aves. São comumente criadas como animais de estimação, e seu manuseio inadequado pode favorecer infecções fúngicas emergentes, as quais podem causar doenças dermatológicas que não são diagnosticadas na natureza. Foram isolados e identificados os fungos filamentosos da microbiota das escamas das serpentes Boidae mantidas em cativeiro no Museu Biológico do Instituto Butantan. Trinta indivíduos de quatro espécies foram avaliados: quatro Eunectes murinus, 12 Boa constrictor constrictor, sete Corallus hortulanus e sete Epicrates crassus. As amostras microbiológicas foram coletadas por fricção, em pequenos quadrados de carpete das escamas das serpentes. Isolaram-se cinco gêneros de fungos: Penicillium sp. (30\%), Aspergillus sp. (25\%), Mucor sp. (25\%), Acremonium sp. (10\%) e Scopulariopsis sp. (10\%). Aproximadamente metade das serpentes avaliadas tinham fungos filamentosos nas escamas e apenas $12 \%$ dos indivíduos foram colonizados por mais de um gênero. Não foram encontrados dermatófitos nas espécies avaliadas. Os resultados mostraram uma visão geral da microbiota fúngica da população de boídeos mantidos no Museu Biológico, o que permitiu a identificação de possíveis patógenos.

Palavras-chave: microbiologia, filamentosos, fungos, répteis

Recebido em 30 de dezembro de 2017

Aceito em 17 de janeiro de 2019

*Autor para correspondência (corresponding author)

E-mail: vivianecgarcia@hotmail.com 


\section{Freire et al.}

\section{INTRODUCTION}

Boids (family Boidae) are non-venomous, constrictor snakes that feed mostly on mammals, reptiles, and birds. Four genera of boids occur in Brazil: Eunectes, Boa, Epicrates, and Corallus. The green anaconda (Eunectes murinus) has semi-aquatic habits and occurs near banks of rivers and lagoons throughout Brazil. Green anacondas feed mostly on small to medium-sized mammals but may occasionally prey on larger mammals such as deer (Kolesnikovas et al., 2007; Puorto and França, 2009). Because of their large size (up to $10 \mathrm{~m}$ snout-vent-length [SVL]), green anacondas can pose dangers to humans (Rivas, 1998). Boa constrictor constrictor is commonly found in dry and mesic habits in Brazil. Females can reach up to $4 \mathrm{~m}$ and males $2.5 \mathrm{~m}$ SVL. They exhibit semiarboreal habits and feed on mammals and birds (Amaral, 1973; Gomes et al., 1989). The species is viviparous, and females give birth to up to 50 young after a gestation period ranging from four to eight months (Wagner, 2006). The rainbow boa (Epicrates crassus) is also common in Brazil, except in the south of the country (Puorto and França, 2009). They are mostly found in areas with moist shaded soils but can also be seen on trees sheltering from floods or foraging for food. Rainbow boas are slow and aggressive (Amaral, 1973). The tree boa (Corallus hortulanus) is widely distributed in South America, inhabiting mainly forest areas, but it can also be found in small urban centers. It is a nocturnal and arboreal species averaging $1.5 \mathrm{~m} \mathrm{SVL}$ (Henderson, 1992).

Keeping these boid species in captivity is a complex task, as it requires experienced workers (to handle such large animals) and suitable temperature, humidity, and ventilation. Constant temperatures combined with high humidity levels contribute to the proliferation of several fungal species, and thus an increased risk of opportunistic infections (Campagner, 2011).

Fungi are ubiquitous and can be parasitic, saprobic, or mutualistic. Most of them are saprophytes that cause opportunistic diseases in specific situations in various animal species, including reptiles (Schumacher, 2003). The fungi present in the mycobiota may become potentially pathogenic in debilitated hosts (Sá and Solari, 2001). Nevertheless, snake mycobiota is poorly known, which makes diagnosis and treatment difficult especially under captive conditions (Pessoa, 2009).

Fungal diseases occur throughout the world and have been reported in all reptilian groups, except in tuatara (Mader, 2006). Fungal infections can cause respiratory infections in snakes and lizards, leading to pneumonia and death (Schumacher, 2003). Suitable husbandry makes domestic reptiles less susceptible to fungal diseases (Mader, 2006; Pessoa, 2009). The main factors responsible for the appearance of fungal infections include low temperature, deficient nutrition, high relative humidity, and immunological diseases (Frye, 1991). Opportunistic infections by filamentous and yeast fungi can also occur in cutaneous mycoses and systemic infections in reptiles (Mader, 2006). The fungi most commonly identified in reptiles include Fusarium spp., Candida sp., Trichosporon sp., Mucor sp., Tricoderma sp., Geotrichum sp., Aspergillus sp., and Penicilium sp. (Hoppmann and Barron, 2007). Here, we identify the filamentous fungi that compose the mycobiota of the scales of boid snakes kept in captivity.

\section{MATERIAL AND METHODS}

The experiment was conducted at the Biological Museum of the Butantan Institute, São Paulo, Brazil, under the approval of the institute's Animal Ethics Committee (approval number 1348/14).

We assessed 30 individual snakes from the collection of the Biological Museum of the Butantan Institute, São Paulo, Brazil. Snakes were kept in two different captive conditions. One group was kept for public display in terraria containing soil, plants, trunks, heaters, and lamps. This group consisted of four E. murinus, three $B$. constrictor, four $C$. hortulanus, and one $E$. crassus. Snakes of the second group were housed in plastic cages $(40 \times 30 \times 28 \mathrm{~cm})$, with corrugated cardboard, water bowls, burrows, and trunks (only for C. hortulanus), in airconditioned rooms. These group consisted of nine $B$. c. constrictor, three $C$. hortulanus, and six E. crassus. The individual snakes assessed were either collected in nature or were born in captivity, quarantined, and healthy. The snake enclosures were cleaned twice a week. Cleaning of the terraria kept for public display involved 
the removal of feces from the soil and disinfection with iodophor. The plastic boxes were washed with soap and water, disinfected with iodophor, and the cardboards were changed.

Snakes were restrained with a snake hook and handled manually. Then a square of wool carpet of approximately $5 \times 5 \mathrm{~cm}$ (Mariat and AdamCampos, 1967) was rubbed on the entire back of the animal. The carpets were properly washed and autoclaved $\left(120^{\circ} \mathrm{C}\right.$ for $\left.20 \mathrm{~min}\right)$ before use to reduce the risk of contamination. After collection, the carpets were placed in styrofoam boxes containing recyclable ice and transported to the Laboratory of Preventive Veterinary Medicine of the Veterinary Complex of the Cruzeiro do Sul University (São Paulo).

Once in the laboratory, samples were pressed against the surface of Petri dishes containing Sabouraud dextrose agar and Mycosel agar media and incubated in an oven at $25^{\circ} \mathrm{C}$ for 21 days. Petri dishes were inspected every three days. Once isolated, colonies were identified based on their macroscopic and microscopic morphological characteristics, as suggested by Riddell (1950) and Larone (1995). For this, we used the slide culture technique proposed by Porto et al. (1981), which consists of growing the pure isolate on a microscope glass slide with agar and a drop of methylene blue. Next, cardboards were coverslipped and examined under a light microscope.

\section{RESULTS}

We found filamentous fungi in $48.8 \%$ of the individual snakes evaluated. All species showed filamentous fungal infection. Eunectes murinus showed the highest fungal diversity followed by B. c. constrictor, C. hortulanus, and E. crassus (Table 1). We identified five different genera of filamentous fungi (Table 1; Figure 1, 2 and 3). All of the infected individuals had more than one filamentous fungus. We found no dermatophytes in the evaluated species.

Table 1. Filamentous fungi identified in the scales of boid snakes kept in captivity

\begin{tabular}{lccccc}
\hline \multirow{2}{*}{$\begin{array}{c}\text { Filamentous } \\
\text { Fungi }\end{array}$} & \multicolumn{5}{c}{ Sunectes } \\
\cline { 2 - 5 } & murinus & $\begin{array}{c}\text { Boa constrictor } \\
\text { constrictor }\end{array}$ & $\begin{array}{c}\text { Corallus } \\
\text { hortulanus }\end{array}$ & $\begin{array}{c}\text { Epicrates } \\
\text { crassus }\end{array}$ & Total \\
\hline Penicillium sp. & 3 & 2 & 1 & 0 & 6 \\
Aspergillus sp. & 1 & 0 & 3 & 1 & 5 \\
Mucor sp. & 2 & 3 & 0 & 0 & 5 \\
Acremonium sp. & 1 & 1 & 0 & 0 & 2 \\
Scopulariopsis sp. & 1 & 0 & 0 & 1 & 2 \\
Total & 8 & 6 & 4 & 2 & 20 \\
\hline
\end{tabular}

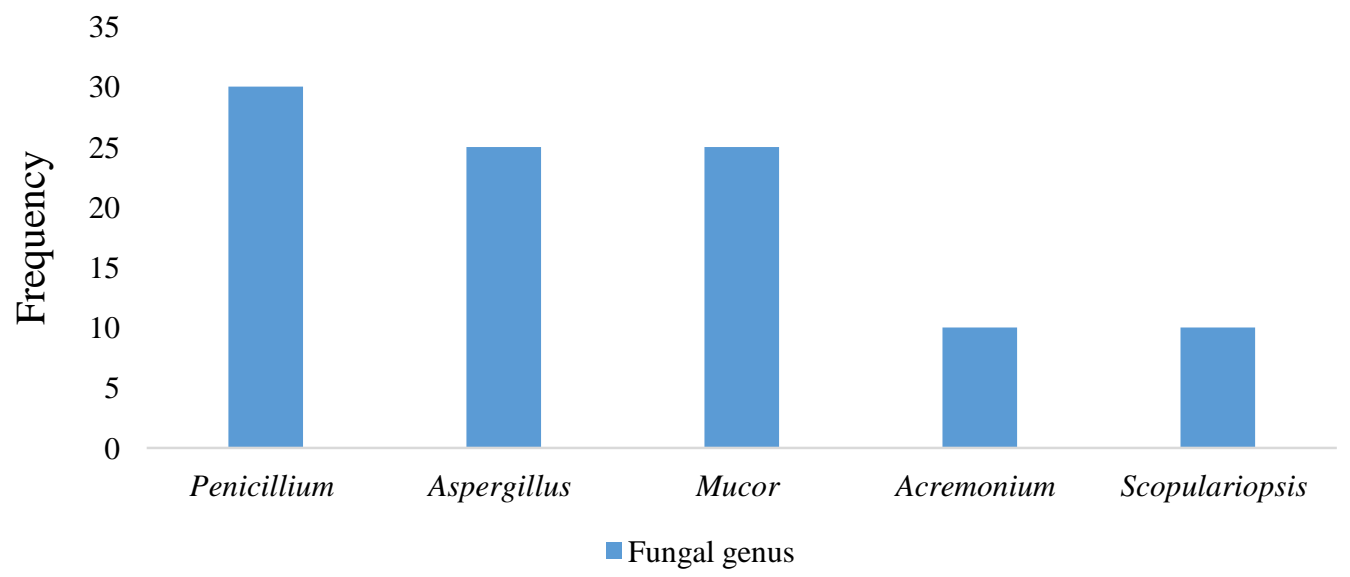

Figure 1. Frequency of filamentous fungi found in boid snakes kept in captivity. 
Freire et al.
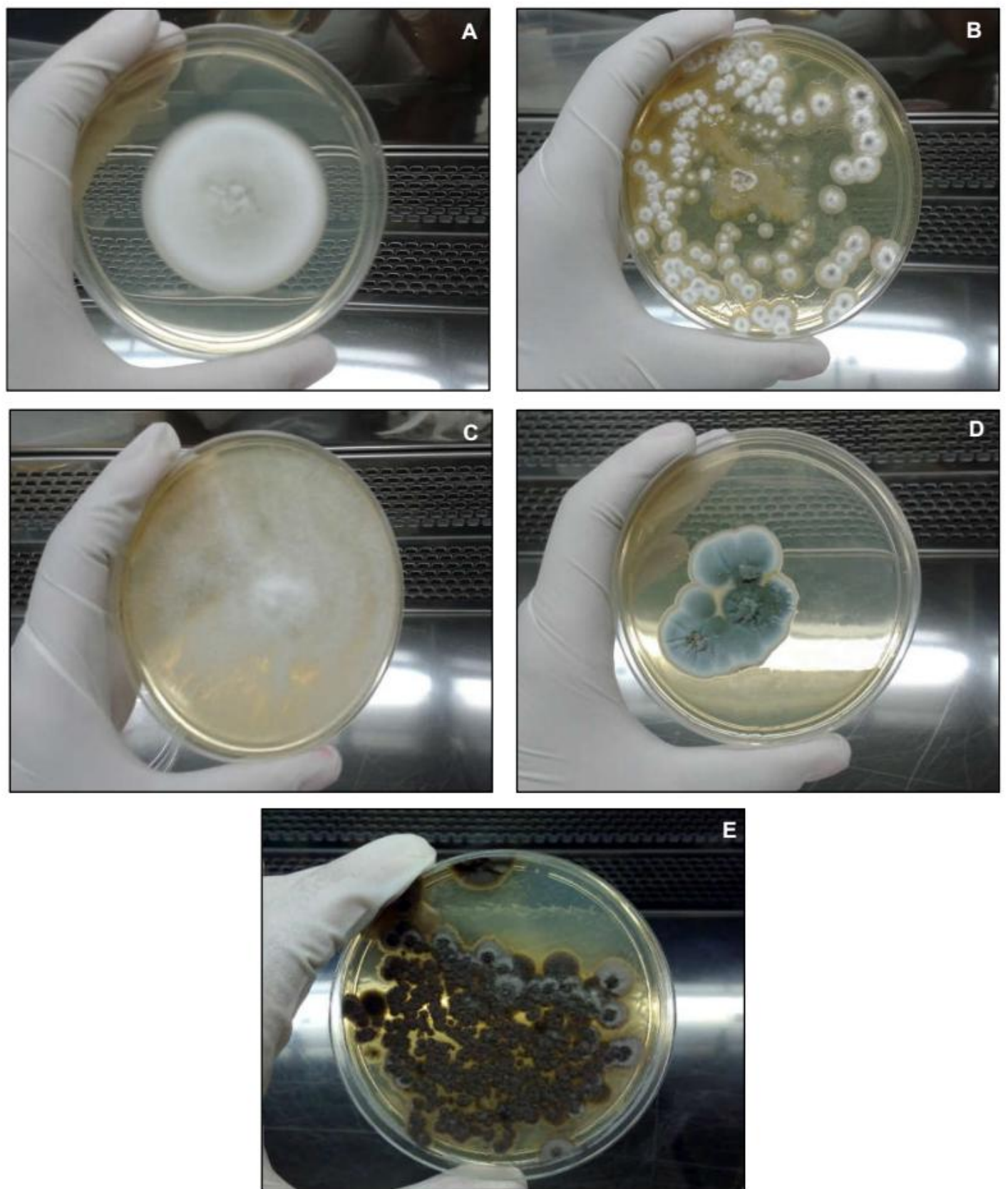

Figure 2. Cultures of filamentous fungi isolated from scales of boid snakes (Eunectes murinus) kept in captivity: A) Acremonium sp.; B) Aspergillus sp.; C) Mucor sp.; D) Penicillium sp.; and E) Scopulariopsis sp. 

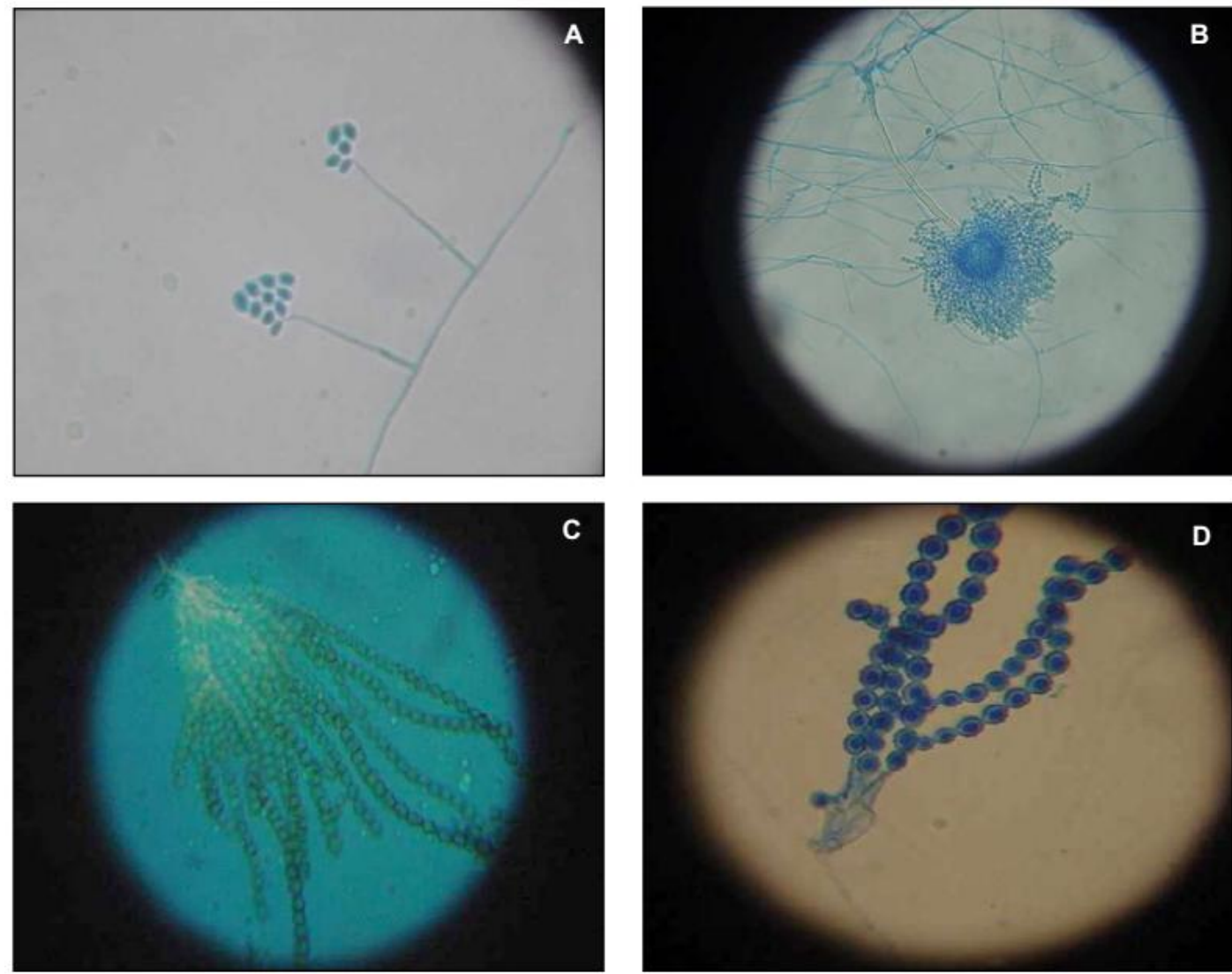

Figure 3. Microscopic morphology of conidias, the filamentous fungi isolated from the scales of boid snakes (Eunectes murinus) kept in captivity. A) Acremonium sp. (200× magnification); B) Aspergillus sp. (200× magnification); C) Penicillium sp. (400× magnification); and D) Scopulariopsis sp. (200× magnification).

\section{DISCUSSION}

Filamentous fungi were isolated from the scales of approximately half of the individuals evaluated, and they had more than one filamentous fungus. E. murinus and Boa $c$. constrictor had higher number and diversity of fungi in the scales likely because they were housed in terraria with direct contact with soil. Although more than half of the individuals of $C$. hortulanus were also housed in terraria with soil, these snakes spent most of their time on tree trunks, thus minimizing contact with the soil. Most of the individuals of E. crassus were housed in plastic boxes without soil and with a higher frequency of cleaning and substrate change, which likely explains the lower infection rate in this species.

The filamentous fungi we identified are saprophytes and usually found in soil, animal feces, decomposing organic matter, and plants (Lacaz et al., 1991). These fungi have been reported as etiological agents of various diseases in humans and domestic animals (Fowler and Miller, 1999; Lacaz et al., 2002). Moreover, these fungi can cause disease in immunocompromised individuals and be lethal under unfavorable conditions (Lacaz et al., 1991). Penicillium and Aspergillus are commonly found in the environment and associated with respiratory tract infections in birds and reptiles (Frye, 2007; Poester et al., 2015). These fungi are often responsible for major economic losses and increasing threat to endangered or non-endangered animals (Hoog, 2000; Lacaz et al., 2002). Mucor spp. are often implicated as the agent of zygomycosis or mucormycosis. These infections are commonly associated with hematologic diseases, diabetic ketoacidosis, and organ transplantation (Lacaz et al., 1991). The most frequent clinical 
presentation is rhinocerebral mucormycosis, with or without pulmonary involvement. Pulmonary zygomycosis usually occurs in immunocompromised patients (Severo et al., 2010). In reptiles, Mucor spp. have been found in cases of pneumonia (Frye, 2007) and considered pathogenic when found in histopathological examination of the skin (Mader, 2006). Our finding of Acremonium sp. in B. c. constrictor and $E$. murinus may be related to the presence of this fungus in the air of the city of São Paulo (Gambale et al., 1983). This fungus is widely distributed in nature, but no colonization or infection has been found in snakes. Similarly, Scopulariopsis sp. can also infect humans and many animals with compromised immune systems, but there are no reports of infection in snakes (Lacaz et al., 1991).

\section{CONCLUSIONS}

Filamentous fungi have low virulence but are opportunistic as they can lead captive snakes to contract life-threatening systemic infections. The prophylactic measures and lower contact with the soil in snakes kept in plastic boxes contributed significantly to the low frequency of fungal isolation in the individuals evaluated. Thus, we propose that prophylactic measures, such as systematic cleaning of the snake enclosures, are highly necessary to avoid fungal contamination in captivity.

\section{ACKNOWLEDGMENTS}

We thank the Cruzeiro do Sul University, PIBIC, and Butantan Foundation for funding this project. We also thank Giuseppe Puorto (head of the Biological Museum) and many other museum staff for their collaboration in this research.

\section{REFERENCES}

AMARAL, A. Ofionimia ameríndia na ofiologia brasiliense. Mem. Inst. Butantan, v.37, p.1-15, 1973.

CAMPAGNER, M.V. Manejo de serpentes em cativeiro: manejo clínico-sanitário e avaliação da microbiota. 2011. 177f. Tese (Doutorado em Doenças Tropicais) - Faculdade de Medicina, Universidade Estadual Paulista Júlio de Mesquita Filho, Botucatu, São Paulo, SP.
FOWLER, M.E.; MILLER, R.E. Zoo and wild animal medicine. Philadelphia: W.B. Saunders, 1999. 747p.

FRYE, F.L. Condições patológicas relacionadas ao ambiente de cativeiro. In.: VILANI, R.G.D.O.C. (Ed.). Grupo Fowler: avanços na medicina de animais selvagens. Curitiba: Fotolaser Gráfica e Editora, 2007. p.100-103.

FRYE, F.L. Reptile care. An atlas of diseases and treatments. Nepture City: TFH Publications, 1991. v.1, 325p.

GAMBAlE, W.; PURCHIO, A.; PAULA, C. Influência de fatores abióticos na dispersão aérea de fungos na cidade de São Paulo, Brasil. Rev. Microbiol. v.14, p.204-214, 1983.

GOMES, N.; PUORTO, G.; BUONONATO, M.A.; RIBEIRO, M.F.M. Atlas anatômico de Boa constrictor Linnaeus, 1758 (Serpentes; Boidae). Monogr. Instit. Butantan, n.2, p.1-59, 1989.

HENDERSON, R.W. Activity patterns, temperature, relationships, and habitat utilization in Corallus enydris (Serpentes Boidae) on Grenada. Caribb. J. Sci., v.28, p.229-232, 1992.

HOOG, G.S. Atlas of clinical fungi. CBS: Utrecht, 2000. 1126p.

HOPPMANN, E.; BARRON, H.W. Dermatology in reptiles. J. Exot. Pet Med. Discipl., v.16, p.210-224, 2007.

KOLESNIKOVAS， C.K.M.; GREGO, K.F.; ALBURQUERQUE, L.C.R. Ordem Squamata Subordem Ophidia (Serpente). In: CATÃODIAS, J.L.; SILVA, J.C.R.; CUBAS, Z.S. (Eds.). Tratado de animais selvagens. São Paulo: Roca, 2007. p.68-85.

LACAZ, C.S.; PORTO, E.; MARTINS, J.E.C. et al. Tratado de micologia médica Lacaz. São Paulo: Sarvier, 2002. 1104p.

LACAZ, C.S.; PORTO, E.; MARTINS, J.E.C. Micologia médica: fungos, actinomicetos e algas de interesse médico. São Paulo: Sarvier, 1991. $695 \mathrm{p}$.

LARONE, D.H. Medically import fungi a guide to identification. Washington: ASM Press, 1995. $274 \mathrm{p}$. 
MADER, D. Reptile medicine and surgery. St. Louis, Missouri: Saunders Elsevier, 2006. p.1242.

MARIAT, F.; ADAM-CAMPOS, A. La techniqu educarré dutapis, method simple de prélevement dansles mycoses superficielles. Ann. Inst. Pasteur, v.113, p.666-668, 1967.

PESSOA, C.A. Avaliação da microbiota bacteriana e fúngica presente na cloaca de jabutis (Geochelone carbonaria) criados em domicílio e análise do potencial risco a saúde humana. 2009. 96f. Dissertação (Mestrado em Ciências). Faculdade de Medicina Veterinária e Zootecnia, Universidade de São Paulo, São Paulo, SP.

POESTER, V.R.; KLAFKE, G.B.; CABANA, A.L. et al. Isolamento e identificação de fungos do gênero Aspergillus spp de água utilizada na reabilitação de pinguins-de-Magalhães. Ciênc. Anim. Bras., v.16, p.567-573, 2015.

PORTO, E.; TAKAHASHI, N.; HEINS, E. M. et al. Mieno método para microcultivo de hongos. Rev. Argent. Micol., v.4, p.24-29, 1981.
PUORTO, G.; FRANÇA, F.O.S. Serpentes não peçonhentas e aspectos clínicos dos acidentes. In.: CARDOSO, J.L.C.; FRANÇA, F.O.S.; WEN, F.H. et al. (Eds.). Animais peçonhentos no Brasil: biologia, clínica e terapêutica dos Acidentes. São Paulo: Sarvier Editora de Livros Médicos, 2009. p.124-129.

RIDDELL, R.W. Permanent mycological preparations obtained by slide culture. Mycopathologia, v.42, p.265-270, 1950.

RIVAS, J.A. Predatory attacks of green anacondas (Eunectes murinus) on adult human beings. Herpetol. Nat. Hist., v.2, p.157-159, 1998.

SÁ, I.; SOLARI, C. Salmonella in Brazilian and imported pet reptiles. Braz. J. Microbiol., v.32, p.293-297, 2001.

SCHUMACHER, J. Fungal diseases of reptiles. Vet. Clin. N. Am. Exotic. Anim. Pract., v.6, p.327-335, 2003.

SEVERO, C.B.; GUAZZELLI, L.S.; SEVERO, L.C. Zigomicose. J. Bras. Pneumol., v.36, p.134141, 2010.

WAGNER, D. Boas - a complete pet ower's manual. New York: Barron's Educational Series, 2006. p.53-89. 